\title{
Environment and the inflammatory bowel diseases
}

\author{
Alexandra Frolkis $\mathrm{BSC}^{1,2}$, Levinus A Dieleman MD PhD ${ }^{3}$, Herman W Barkema DVM PhD ${ }^{2,4}$, Remo Panaccione $\mathrm{MD}^{1,2}$, \\ Subrata Ghosh $\mathrm{MD}^{1,2}$, Richard N Fedorak $\mathrm{MD}^{3}$, Karen Madsen PhD ${ }^{3}$, Gilaad G Kaplan MD MPH FRCPC ${ }^{1,2,4}$; \\ on behalf of the Alberta IBD Consortium
}

\begin{abstract}
A Frolkis, LA Dieleman, HW Barkema, et al; on behalf of the Alberta IBD Consortium. Environment and the inflammatory bowel diseases. Can J Gastroenterol 2013;27(3):e18-e24.

Inflammatory bowel diseases (IBD), which consists of Crohn disease and ulcerative colitis, are chronic inflammatory conditions of the gastrointestinal tract. In genetically susceptible individuals, the interaction between environmental factors and normal intestinal commensal flora is believed to lead to an inappropriate immune response that results in chronic inflammation. The incidence of IBD have increased in the past century in developed and developing countries. The purpose of the present review is to summarize the current knowledge of the association between environmental risk factors and IBD. A number of environmental risk factors were investigated including smoking, hygiene, microorganisms, oral contraceptives, antibiotics, diet, breastfeeding, geographical factors, pollution and stress. Inconsistent findings among the studies highlight the complex pathogenesis of IBD. Additional studies are necessary to identify and elucidate the role of environmental factors in IBD etiology.
\end{abstract}

Key Words: Crohn disease; Environment; Epidemiology; Inflammatory bowel disease; Ulcerative colitis; Risk factors

Tnflammatory bowel disease (IBD), which includes Crohn disease (CD) and ulcerative colitis (UC), is a chronic inflammatory condition of the gastrointestinal tract whose pathogenesis is not completely understood. The prevailing theory is that IBD arises from a combination of genetic susceptibility and exposure to environmental risk factors (1). Genome-wide association scans have identified more than 100 genes that increase susceptibility to CD and UC (2-3). The identification of genetic determinants have provided insight into the pathogenesis of IBD but have not fully explained disease pathogenesis. This is highlighted by a Swedish twin study (4), which demonstrated a stronger heredity factor in CD over UC among monozygotic twins, with a concordance rate of $58 \%$ for CD and only $6 \%$ for UC. Incomplete gene penetrance suggests that additional factors influence disease pathogenesis (5). Furthermore, genetic susceptibility does not explain the rise in incidence of IBD observed in developed and, now, in developing nations (6).

IBD was primarily recognized in westernized countries following the rise of the industrial revolution. The incidence of IBD dramatically increased during the 20th century (7). IBD is most prevalent in developed nations such as Canada, the United States and Western Europe $(7,8)$. The incidence of IBD in these developed nations is as high as 20 and 24 cases per 100,000 person-years for CD and UC, respectively (8). As developing countries, such as India and China, became industrialized, the incidence of IBD has risen in parallel (9-11). Additionally, as individuals move from areas of low to high prevalence of IBD, first-generation offspring acquire the same risk of

\section{L'environnement et les maladies inflammatoires de l'intestin}

Les maladies inflammatoires de l'intestin (MII), qui incluent la maladie de Crohn et la colite ulcéreuse, sont des maladies inflammatoires chroniques du tube digestif. Chez les personnes qui y sont génétiquement susceptibles, on pense que l'interaction entre les facteurs environnementaux et la flore commensale intestinale normale entraîne une réponse immunitaire inadéquate qui suscite une inflammation chronique. L'incidence de MII a augmenté depuis un siècle dans les pays industrialisés et les pays en développement. La présente analyse vise à résumer les connaissances actuelles sur l'association entre les facteurs de risque environnementaux et les MII. Les chercheurs ont exploré plusieurs facteurs de risque environnementaux, y compris le tabagisme, l'hygiène, les microorganismes, les contraceptifs oraux, les antibiotiques, le régime, l'allaitement, les facteurs géographiques, la pollution et le stress. Les résultats contradictoires entre les études font ressortir la pathogenèse complexe des MII. D'autres études s'imposent pour déterminer et clarifier le rôle des facteurs environnementaux dans l'étiologie des MII.

developing IBD as the local population $(12,13)$. This shift in risk suggests that changes in environment - in addition to genetic predisposition - contribute to the development of IBD.

Multiple studies have explored the relationship between IBD and environment; however, these studies have not completely elucidated the association between the environment and IBD (14). In the present review, we explore the current knowledge of the association between commonly studied environmental exposures and IBD (Table 1).

\section{SMOKING}

Smoking has long been known to affect IBD. A meta-analysis implicated smoking as a risk factor for $\mathrm{CD}$ and a protective factor for UC (15). In patients with $\mathrm{CD}$, smoking worsens prognosis by increasing the frequency of disease flares and the the need for surgery, in addition to increasing postoperative recurrence $(16,17)$. Smoking cessation is a key therapeutic strategy in patients with CD (16). In contrast, smoking appears to be protective against UC, with the majority of UC patients being nonsmokers or exsmokers (18). The relationship between IBD and smoking follows a dose-response relationship, with current smokers followed by exsmokers at greatest risk for development of $\mathrm{CD}$, and exsmokers followed by nonsmokers at greatest risk for UC (19-21).

However, another meta-analysis did not demonstrate an association between IBD and childhood passive smoke exposure, or prenatal smoke exposure (19). Smoking may only influence the development of IBD in adults. Passive smoking may not contribute sufficient levels of

${ }^{1}$ Inflammatory Bowel Disease Clinic, Division of Gastroenterology, Departments of Medicine; ${ }^{2}$ Community Health Sciences; University of Calgary, Calgary; ${ }^{3}$ Department of Medicine, University of Alberta, Edmonton; ${ }^{4}$ Production Animal Health, University of Calgary, Calgary, Alberta

Correspondence: Dr Gilaad G Kaplan, Departments of Medicine and Community Health Sciences, University of Calgary, Teaching Research and Wellness Centre, 3280 Hospital Drive Northwest, 6th Floor, Room 6D56, Calgary, Alberta T2N 4N1. Telephone 403-592-5015, fax 403-592-5090,

e-mail ggkaplan@ucalgary.ca

Received for publication July 13, 2012. Accepted August 13, 2012 
smoke and associated chemicals to elicit a response. However, measuring an individual's exposure to passive smoking is more difficult compared with direct smoking exposure. Thus, methodological challenges in studying passive smoking exposure may account for the lack of an observed association (22).

Smoking may influence the development of IBD through nicotinic acetylcholine receptors, which are present in mucosal epithelial cells of the bowel (23), and on T cells (24). Clinical trials of nicotine replacement in UC have yielded modest yet inconsistent results; thus, nicotine alone may not be the sole component of smoking that influences IBD (25). Other proposed mechanisms are that chemicals in smoking modulate cellular immunity (26), alter cytokine levels (27), modify colonic mucus production (28), and predispose to the development of microvascular thrombi or altered blood flow $(25,29)$.

Although smoking is an important part of IBD pathogenesis, the highest incidence of $\mathrm{CD}$ actually occurs in countries with a low prevalence of smoking such as Canada $(30,31)$. In contrast, many countries with a low incidence of CD, such as South Korea, have a much higher smoking prevalence than Canada (32). The majority of CD patients are nonsmokers and the majority of smokers do not develop CD. Thus, smoking's impact on IBD development is multifactorial and not universal.

\section{HYGIENE AND MICROORGANISMS}

\section{Hygiene hypothesis}

The hygiene hypothesis suggests that improved sanitation and reduced exposure to enteric organisms during childhood leads to inappropriate immunological responses later in life (33). Several proxy markers of childhood hygiene have been studied. Living with multiple siblings increases the exposure to enteric bacteria in childhood, which may reduce the risk of developing of IBD later in life $(33,34)$. One study determined that $\mathrm{CD}$ patients are more likely to live in smaller households with fewer siblings (35). However, this was not found in UC (35). Other studies have found that having older siblings is associated with an increased risk of UC, while having younger siblings is associated with a decreased risk of CD (36). Additionally, higher birth rank has been associated with decreased risk of both CD and UC (37). Exposure to cats in early life was a risk factor in pediatric-onset CD (35). However, one study found that patients with adult-onset CD were significantly less likely to have lived with cats before five years of age (38). Living on a farm in childhood, living in more crowded homes and consuming unpasteurized milk are associated with decreased risk of IBD, although this decrease is seen more commonly in CD than UC $(35,38,39)$.

\section{Helicobacter pylori}

H pylori, a pathogen involved in peptic ulcer disease, is a bacterium that is associated with larger family size, multiple siblings and poor sanitary conditions (40). A meta-analysis (41) reported that CD and UC are negatively associated with $\mathrm{H}$ pylori. $\mathrm{H}$ pylori increases the expression of $\mathrm{T}$ cell regulatory genes, such as Foxp3, resulting in an anti-inflammatory response (41). Alternatively, $H$ pylori may not be causally related to IBD, but instead is a proxy marker of the 'hygiene hypothesis'. Reduced colonization of $H$ pylori in IBD patients may be secondary to more frequent antibiotic use before the diagnosis of IBD or a consequence of improved childhood sanitary living conditions (34).

\section{Helminths}

Colonization of parasitic worms (ie, helminths) may be associated with a reduced prevalence of IBD. Helminths play an important immunoregulatory role in the intestinal flora $(42,43)$. Open-label clinical trials of helminth treatment demonstrate a potential benefit for both UC and CD, which is likely due to the ability of the parasite to upregulate immunoregulatory and anti-inflammatory cytokines (eg, interleukin-10 and interleukin-4) (44,45). A randomized controlled trial found that UC patients treated with Trichuris suis ova, a type of helminth, were more likely to improve their disease state compared with UC patients who received placebo (46).
TABLE 1

Environmental risk factors for the inflammatory bowel diseases

\begin{tabular}{|c|c|c|}
\hline \multirow[b]{2}{*}{ Environmental risk factor } & \multicolumn{2}{|c|}{ Strength of association* } \\
\hline & Crohn disease & Ulcerative colitis \\
\hline \multicolumn{3}{|l|}{ Smoking } \\
\hline Current & Strong positive & Strong negative \\
\hline Previous & Strong positive & Strong positive \\
\hline Never & Negative & Positive \\
\hline \multicolumn{3}{|l|}{ Hygiene } \\
\hline Multiple siblings & Questionable negative & Questionable negative \\
\hline Farm in childhood & Questionable negative & Questionable negative \\
\hline \multicolumn{3}{|l|}{ Microorganisms } \\
\hline Helicobacter pylori & Negative & Negative \\
\hline Helminths & Negative & Negative \\
\hline $\begin{array}{l}\text { Myobacterium avium } \\
\text { spp paratuberculosis }\end{array}$ & Positive & Not studied \\
\hline Dysbiosis & Positive & Not studied \\
\hline Urban living environment & Questionable positive & Questionable positive \\
\hline \multicolumn{3}{|l|}{ Medication } \\
\hline $\begin{array}{l}\text { Nonsteroidal anti- } \\
\text { inflammatory drugs }\end{array}$ & Positive & Positive \\
\hline Oral contraceptive pills & Positive & Positive \\
\hline Isotretinoin & Questionable positive & Questionable positive \\
\hline Antibiotics & Questionable positive & Questionable positive \\
\hline Appendectomy & Not associated & Negative \\
\hline \multicolumn{3}{|l|}{ Nutrition } \\
\hline Fruits and vegetables & Questionable negative & Questionable negative \\
\hline Fat & Questionable positive & Questionable positive \\
\hline Sugar/sweeteners & Questionable positive & Questionable positive \\
\hline Animal protein & Not studied & Questionable positive \\
\hline Fibre & Questionable negative & Questionable negative \\
\hline Breastfeeding & Questionable negative & Questionable negative \\
\hline Northern residence & Positive & Positive \\
\hline \multicolumn{3}{|l|}{ Ambient air pollution } \\
\hline Sulfur dioxide & $\begin{array}{l}\text { Questionable not } \\
\text { associated }\end{array}$ & Questionable positive \\
\hline $\begin{array}{l}\text { Nitrogen dioxide in } \\
\text { children }\end{array}$ & Questionable positive & $\begin{array}{l}\text { Questionable not } \\
\text { associated }\end{array}$ \\
\hline $\begin{array}{l}\text { Nitrogen dioxide in } \\
\text { middle-age adults }\end{array}$ & Questionable negative & $\begin{array}{l}\text { Questionable not } \\
\text { associated }\end{array}$ \\
\hline Stress & Questionable positive & Questionable positive \\
\hline
\end{tabular}

*Strength of association based on information from included studies. spp Subspecies

\section{Mycobacterium avium subspecies paratuberculosis}

Several diseases in animals parallel the clinical presentation of IBD. One such example is Johne's disease in cattle, which has clinical and histological similarities to CD (6). M avium subspecies paratuberculosis (MAP) has been implicated as a potential cause of CD in humans because of its similar clinical effect on Johne's disease in cattle (6). MAP is detectable in the intestinal tissue and blood of a subset of CD patients, and antimycobacterial drugs have been found, in some cases, to improve disease (47). A meta-analysis of case-control studies (48) reported a positive association between MAP and CD when either ELISA or polymerase chain reaction techniques were used to detect MAP. However, the role of MAP in CD is unclear. MAP may induce $\mathrm{CD}$ in a subset of patients, or CD may increase the frequency of intestinal colonization of MAP. The results of a large, double-blinded placebo-controlled trial (49) suggested that treatment of MAP was not associated with long-term remission. While the use of biologicals is associated with increased incidence of pulmonary tuberculosis in IBD patients, immune suppression is not associated with widespread 
MAP infections. Thus, the exact relationship between MAP and CD remains inconclusive.

\section{Other microorganisms}

Pathogenic bacteria, such as Salmonella and Campylobacter, as well as acute gastroenteritis have been implicated in IBD pathogenesis. Adherent-invasive Escherichia coli was associated with the ileal phenotype of CD $(50,51)$. CD patients with NOD2 variants, which predispose to the $\mathrm{CD}$ ileitis phenotype, exhibit a reduced proinflammatory cytokine response to adherent-invasive E coli (52). Invasive strains of Fusobacterium nucleatum were discovered in actively inflamed IBD patients (53). Alternatively, increased use of refrigeration has allowed psychotrophic intracellular bacteria, such as Listeria monocytogenes and Yersinia enterocolitica, to thrive in modern societies. Exposure to these pathogenic organisms may increase the risk of developing IBD $(42,43)$.

\section{Dysbiosis}

Dysbiosis, which refers to a condition of microbial imbalances in the intestine, is associated with CD (54). A recent case-control study focused on fecal microbiota of CD patients, their unaffected relatives and unrelated controls (55), and identified five bacterial species that characterized dysbiosis: a decrease in Dialister invisus, Faecalibacterium prausnitzii and Bifidovacterium adolescentis; and an increase in Ruminococcus gnavus. The unaffected relatives, in contrast, had fewer Collinsella aerofaceins and more Ruminococcus torques than the unrelated controls (55). The mechanisms by which these bacteria contribute to $\mathrm{CD}$ development requires further study; however, an increase in mucin-degrading bacterium ( $R$ gnavus) may predispose individuals to CD (55).

\section{Urban versus rural environment}

Multiple studies have investigated the association between urban areas and IBD, yielding inconsistent results. Several observational studies have shown that the incidence of both CD and UC was increased in densely populated areas (56-58). However, other studies have failed to find an association between urban areas and IBD (59-60), whereas one European study (40) found a protective association. These inconsistencies could be due to multiple definitions of 'urban', in addition ot poor study design (22). Studies of IBD in rural areas are sparse, which could be due to poor access to information in rural areas and/or the definitions of what constitutes a rural area.

\section{MEDICATIONS}

\section{Nonsteroidal anti-inflammatory drugs}

A prospective cohort study of more than 76,000 women, as part of the Nurses' Health Study (61), identified an increased absolute risk of both UC and CD in women who used nonsteroidal anti-inflammatory drugs (NSAIDs) at least 15 days per month. Additionally, a casecontrol study investigating the association between NSAIDs and IBD found a positive association in UC and CD (62). In a cohort of IBD patients in remission, NSAIDs were associated with a $15 \%$ to $30 \%$ rate of relapse within nine days of ingestion (63). In contrast, IBD patients in remission did not experience a relapse while on acetaminophen (63). However, a recent population-based study of triggers of symptomatic flares in IBD (64) found that NSAIDs did not increase the risk of IBD flares. NSAIDs increase intestinal permeability by inhibiting cyclo-oxygenase, which in turn reduces prostaglandin production (65). Reduced prostaglandin production has been implicated in IBD through the inhibition of tumour necrosis factor and the induction of anti-inflammatory cytokines (65).

\section{Oral contraceptive pills}

A meta-analysis suggested that the use of oral contraceptive pills (OCPs) was positively associated with UC and CD (66). The risk of $\mathrm{CD}$ was greater with prolonged exposure to OCPs, and women who discontinued OCPs were no longer at a significantly increased risk for
CD. A prospective cohort study (67) found that women who continued to take OCPs were at a threefold increased risk of developing a relapse of $\mathrm{CD}$; this effect was amplified among women who were prescribed OCPs and smoked.

The mechanism by which OCPs increases the risk of IBD is unknown, but the effect may be promoted by estrogen and moderated by progesterone (68). Estrogen is an immune enhancer, specifically affecting humoral immunity and proliferation of macrophages (68). In contrast, progesterone acts as an immune suppressor (68).

\section{Isotretinoin}

Isotretinoin is a retinoid (ie, a vitamin A derivative), used to regulate epithelial cell growth and to treat severe acne and certain cancers. The United States Food and Drug Administration's Medwatch program reported several cases of IBD following the prescription of isotretinoin as an acne medication (69). However, results of case-control studies have been inconsistent. One study reported that isotretinoin was associated with UC, but not CD (70), whereas another found no relationship between isotretinoin and IBD (71). Retinoids are involved in the regulation of the intestinal mucosal immune response (72); however, the mechanism by which isotretinoin influences the development of IBD has yet to be elucidated.

\section{Antibiotics}

Colonization of the gut begins after birth through the introduction of bacteria by infant diet, hygiene level and medication exposure (73). Antibiotic exposure in childhood is hypothesized to disrupt the development of the body's natural tolerance to enteric bacteria, which may lead to IBD $(74,75)$. Several studies have demonstrated a positive association between antibiotic use and the development of IBD $(75,76)$. Additionally, exposure to antibiotics in the first year of life was associated with an increased risk of pediatric-onset CD (77). However, antibiotics are difficult to study because patients with undiagnosed IBD may be prescribed antibiotics to treat symptoms of IBD that are believed to be due to a gastrointestinal infection (76).

\section{APPENDECTOMY}

A meta-analysis found that appendectomy posed a significant risk of CD development (78). This risk, however, was primarily observed within the first year following appendectomy when incipient CD may lead to undue appendectomies $(78,79)$. Five years following appendectomy, the risk of developing CD was no longer significant, which suggests that a biological association between appendectomy and the development of CD may not exist (78).

In contrast, appendicitis has been consistently shown to protect against the development of UC in meta-analyses (80-82). Children who experience appendicitis before 10 years of age were at decreased risk of UC $(83,84)$. The mechanism by which appendicitis protects against UC is not clear; however, the appendix may have a physiological role in antigen sampling and regulating the immunological response to intestinal microflora $(82,85)$.

\section{Diet}

\section{NUTRITION}

The realtionship between diet and IBD has been studied extensively (86); however, the findings should be interpreted with caution because patients may change their diet before diagnosis to reduce disease symptoms. Studies have found that a high intake of dietary fibre, including fruits and vegetables, protects against $\operatorname{IBD}(87,88)$. A case-control study found that CD was associated with the intake of total fats (89). The same study demonstrated a negative relationship between carbohydrate consumption and IBD. Consumption of sugars and/or sweeteners and fats were associated with an increased risk of CD in Asian and North American populations $(89,90)$. Similar associations were found between UC and monounsaturated and polyunsaturated fat consumption (91).

Recent prospective studies have provided new insights into the association between diet and IBD development. One hundred twenty- 
six cases of UC were diagnosed in a cohort of more than 200,000 healthy adults who were followed for a median of four years. Food frequency questionnaires were administered before the diagnosis of UC. Individuals with the highest consumption of linoleic acid, which is present in red meat, oil and certain margarines, were at increased risk of developing UC (92). Another prospective cohort study involving more than 65,000 healthy middle-age women followed for a median of 4.5 years identified 77 new cases of IBD. Dietary questionnaires were completed at baseline. The results suggested that consumption of animal protein - including meat and fish, but not eggs or dairy - significantly increased the risk of IBD development (93). Ananthakrishnan et al (94) used the Nurses' Health Study to demonstrate that high-fibre intake, recorded before the diagnosis of IBD, was associated with a significant $30 \%$ risk reduction of CD. In contrast, dietary intake did not influence the development of UC (94). These studies, however, were limited by small sample sizes, which reduced the power to explore these relationships in greater detail.

\section{Breastfeeding}

Breastfeeding, which protects infants against many immune diseases, may also reduce the risk of IBD development (95). Breastfeeding helps develop oral tolerance to microflora and food antigens, which may prevent IBD $(42,95)$. Lactoferrin, which is present in breast milk, but is absent in formula, may have anti-inflammatory characteristics $(42,96)$. Several studies support a protective association between breastfeeding and IBD $(95,97)$, others have found breastfeeding to be a risk factor $(34,98)$, whereas some fail to find an association (99-101). A metaanalysis reported that breastfeeding reduced the risk of developing IBD (95). A second meta-analysis evaluating only pediatric-onset IBD demonstrated a significant protective effect for early-onset IBD (101). However, significance was lost when pooled studies were stratified according to CD and UC (101).

\section{GEOGRAPHICAL RISK FACTORS}

The prevalence of IBD has been considered in the context of a northsouth gradient, with higher prevalence reported in countries with northern latitudes $(6,102)$. For example, studies using geographical information systems demonstrate a north-south gradient in France for CD, but not for UC $(103,104)$. However, a study published from the Nurses' Health Study (105) found that for both CD and UC, women who were diagnosed after 30 years of age had a significantly lower risk of living in a southern state than a northern state. One potential explanation is differences in exposure to ultraviolet light, resulting in relative vitamin $\mathrm{D}$ deficiencies in northern countries (106). The Nurses' Health Study found that women in the top two quartiles of plasma levels of vitamin D (ie, calcifediol) had significantly lower risk of developing CD compared with women in the lowest quartile (107). Activated vitamin D (ie, calcitriol) can modulate the innate immune system (108). Sunlight exposure with subsequent increased vitamin D levels, may be involved in downregulating a T-helper 1 proinflammatory response (106).

\section{AMBIENT AIR POLLUTION}

Children and young adults living in areas with high sulfur dioxide (an industrial-based pollutant) concentrations were at an increased risk of developing UC (109). Furthermore, children and young adults living in areas of high nitrogen dioxide (a known traffic-related pollutant) concentrations were at increased risk for CD (109). Paradoxically, nitrogen dioxide was negatively associated with the onset of $\mathrm{CD}$ in middle-age adults (109). This finding highlights that environmental exposures may have age-specific effects. Another study demonstrated that hospitalizations for IBD flares were more frequent in counties with higher concentrations of ambient air pollutants (110). Air pollution has also been implicated in triggering appendicitis (111) and nonspecific abdominal pain (112). The mechanism by which air pollution influences the development of IBD is unknown; however, animals fed urban air particles experienced a proinflammatory response and alterations in gut microflora (112). Future studies are necessary to validate these findings and to determine the biological plausibility of the effect of air pollution on IBD.

\section{STRESS}

Stress may play a role in IBD pathogenesis but is, however, more likely to modulate rather than initiate disease activity (113). Both chronic and acute stress can alter immune function and, in turn, may influence the natural course of IBD (114). Results from observational studies $(114,115)$ are inconsistent. One prospective study found that CD patients with poor perceived stress and coping strategies were more likely to experience an early relapse of their disease (116). Animal models also suggest that chronic stress may exacerbate IBD by promoting damage to the intestinal mucosa and increasing intestinal permeability, which reduces the efficay of the intestinal barrier against invading organisms $(117,118)$.

\section{SUMMARY}

Several environmental factors have been associated with IBD, such as smoking, hygiene, microorganisms, OCPs, NSAIDs, antibiotics, appendectomy, diet, breastfeeding, vitamin $\mathrm{D}$, stress and ambient air pollution. However, a clear mechanism by which these environmental risk factors interact to cause IBD has not been elucidated. Furthermore, most risk factors have not been consistently demonstrated across studies. The significant heterogeneity among studies may be due to methodological challenges associated with studying environmental risk factors in IBD. The next generation of environmental health studies should explore environmental risk factors in the context of genetic susceptibility and IBD phenotypes. Therefore, continued research is necessary to better identify and understand the mechanisms of environmental determinants of IBD.

ACKNOWLEDGEMENTS: Dr G Kaplan is supported through a New Investigator Award from the Canadian Institute of Health Research and a Population Health Investigator Award from the Alberta Heritage Foundation for Medical Research. Alexandra Frolkis is supported through an Alberta Innovates - Health Solutions studentship award. The paper was supported by The Alberta IBD Consortium, which is funded by an AHFMR Interdisciplinary Team Grant. AHFMR is now Alberta Innovates - Health Solutions.

\section{REFERENCES}

1. Pierik M, Yang H, Barmada MM, et al. The IBD international genetics consortium provides further evidence for linkage to IBD4 and shows gene-environment interaction. Inflamm Bowel Dis 2006;11:1-7.

2. Barrett JC, Hansoul S, Nicolae DL, et al. Genome-wide association defines more than 30 distinct susceptibility loci for Crohn's disease. Nat Genetics 2008;40:955-62.

3. Gaya DR, Russell RK, Nimmo ER, Satsangi J. New genes in inflammatory bowel disease: Lessons for complex diseases? Lancet 2006;367:1271-84.

4. Tysk C, Lindberg E, Järnerot G, Flodérus-Myrhed B. Ulcerative colitis and Crohn's disease in an unselected population of monozygotic and dizygotic twins. A study of heritability and the influence of smoking. Gut 1988;29:990-6.

5. Halfvarson J, Bodin L, Tysk C, Lindberg E, Järnerot G. Inflammatory bowel disease in a Swedish twin cohort: A long-term follow-up of concordance and clinical characteristics. Gastroenterology 2003;124:1767-73.

6. Loftus EV. Clinical epidemiology of inflammatory bowel disease: Incidence, prevalence, and environmental influences. Gastroenterology 2004;126:1504-17.

7. Molodecky N, Soon IS, Rabi D, et al. Increasing incidence of inflammatory bowel disease with time and among regions, based on systematic review. Gastroenterology 2012;142:46-54. Epub 2011 Oct 14.

8. Molodecky NA, Soon IS, Rabi DM, et al. Increasing incidence and prevalence of the inflammatory bowel diseases with time, based on systematic review. Gastroenterology 2012;142:46-54; e42. 
9. Loftus EV, Sandborn WJ. Epidemiology of inflammatory bowel disease. Gastroenterol Clin N Am 2002;31:1-20.

10. Zheng JJ, Zhu XS, Huangfu Z, Gao ZX, Guo ZR, Wang Z. Crohn's disease in mainland China: A systematic analysis of 50 years of research. Chin J Dig Dis 2005;6:175-81.

11. Desai HG, Gupte PA. Increasing incidence of Crohn's disease in India: Is it related to improved sanitation? Ind J Gastroenterol 2005;24:23-4.

12. Montgomery SM, Morris DL, Pounder RE, Wakefield AJ. Asian ethnic origin and the risk of inflammatory bowel disease. Eur J Gastroenterol Hepatol 1999;11:543-6.

13. Bernstein CN, Shanahan F. Disorders of a modern lifestyle: Reconciling the epidemiology of inflammatory bowel diseases. Gut 2008;57:1185-91.

14. Molodecky NA, Kaplan GG. Environmental risk factors for inflammatory bowel disease. Gastroenterol Hepatol (NY) 2010;6:339-46.

15. Calkins BM. A meta-analysis of the role of smoking in inflammatory bowel disease. Dig Dis Sci 1989;34:1841-54.

16. Rubin DT, Hanauer SB. Smoking and inflammatory bowel disease. Eur J Gastroenterol Hepatol 2000;12:855-62.

17. Cosnes J, Carbonnel F, Beaugerie L, Le Quintrec Y, Gendre J. Effects of cigarette smoking on the long-term course of Crohn's disease. Gastroenterology 1996;110:424-31.

18. Boyko EJ, Koepsell TD, Perera DR, Inui TS. Risk of ulcerative colitis among former and current cigarette smokers. N Engl J Med 1987;316:707-10.

19. Jones DT, Osterman MT, Bewtra M, Lewis JD. Passive smoking and inflammatory bowel disease: A meta-analysis. Am J Gastroenterol 2008;103:2382-93.

20. Persson PG, Ahlbom A, Hellers G. Inflammatory bowel disease and tobacco smoke - a case-control study. Gut 1990;31:1377-81.

21. Franceschi S, Panza E, Vecchia CL, Parazzini F, Decarli A, Porro GB. Nonspecific inflammatory bowel disease and smoking. Am J Epidemiol 1987;125:445-52.

22. Molodecky NA, Panaccione R, Ghosh S, Barkema HW, Kaplan GG. Challenges associated with identifying the environmental determinants of the inflammatory bowel diseases. Inflamm Bowel Dis 2011;17:1792-9.

23. Richardson CE. Effect of smoking and transdermal nicotine on colonic nicotinic acetylcholine receptors in ulcerative colitis. QJM 2003;96:57-65.

24. Razani-Boroujerdi S, Boyd RT, Davila-Garcia MI, et al. T cells express \{alpha\}7-nicotinic acetylcholine receptor subunits that require a functional TCR and leukocyte-specific protein tyrosine kinase for nicotine-induced $\mathrm{Ca}^{2+}$ response. J Immunol 2007;179:2889-98.

25. Birrenbach T, Böcker U. Inflammatory bowel disease and smoking. A review of epidemiology, pathophysiology, and therapeutic implications. Inflamm Bowel Dis 2006;10:848-59.

26. Miller L, Goldstein G, Murphy M, Ginns L. Reversible alterations in immunoregulatory $\mathrm{T}$ cells in smoking. Analysis by monoclonal antibodies and flow cytometry. Chest 1982;82:526-9.

27. Sher ME, Bank S, Greenberg R, et al. The influence of cigarette smoking on cytokine levels in patients with inflammatory bowel disease. Inflamm Bowel Dis 2007;5:73-8.

28. Cope GF, Heatley RV, Kelleher JK. Smoking and colonic mucus in ulcerative colitis. BMJ (Clinical research edn) 1986;293:481.

29. Sawyerr AM, Wakefield AJ, Hudson M, Dhillon AP, Pounder RE. The pharmacological implications of leucocyte-endothelial cell interactions in Crohn's disease. Aliment Pharmacol Ther 1991;5:1-14.

30. Shields M. Smoking bans: Influence on smoking prevalence. Health reports / Statistics Canada, Canadian Centre for Health Information $=$ Rapports sur la santé $/$ Statistique Canada, Centre canadien d'information sur la santé. 2007;18:9-24.

31. Bernstein CN, Wajda A, Svenson LW, et al. The epidemiology of inflammatory bowel disease in Canada: A population-based study. Am J Gastroenterol 2006;101:1559-68.

32. Ouyang Q, Tandon R, Goh K-L, Ooi CJ, Ogata H, Fiocchi C. The emergence of inflammatory bowel disease in the Asian Pacific region. Curr Opin Gastroenterol 2005;21:408-13.

33. Gent AE, Hellier MD, Grace RH, Swarbrick ET, Coggon D. Inflammatory bowel disease and domestic hygiene in infancy. Lancet 1994;343:766-7.
34. Baron S, Turck D, Leplat C, et al. Environmental risk factors in paediatric inflammatory bowel diseases: A population based case control study. Gut 2005;54:357-63.

35. Bernstein CN, Rawsthorne P, Cheang M, Blanchard JF. A population-based case control study of potential risk factors for IBD. Am J Gastroenterol 2006;101:993-1002.

36. Montgomery SM, Lambe M, Wakefield AJ, Pounder RE, Ekbom A. Siblings and the risk of inflammatory bowel disease. Scand J Gastroenterol 2002;37:1301-8.

37. Hampe J, Heymann K, Krawczak M, Schreiber S. Association of inflammatory bowel disease with indicators for childhood antigen and infection exposure. Int J Colorect Dis 2003;18:413-7.

38. Amre DK, Lambrette P, Law L, et al. Investigating the hygiene hypothesis as a risk factor in pediatric onset Crohn's disease: A case-control study. Am J Gastroenterol 2006;101:1005-11.

39. Lashner BA, Loftus EV. True or false? The hygiene hypothesis for Crohn's disease. Am J Gastroenterol 2006;101:1003-4.

40. Feeney MA, Murphy F, Clegg AJ, Trebble TM, Sharer NM, Snook JA. A case-control study of childhood environmental risk factors for the development of inflammatory bowel disease. Eur J Gastroenterol Hepatol 2002;14:529-34.

41. Luther J, Dave M, Higgins PDR, Kao JY. Association between Helicobacter pylori infection and inflammatory bowel disease: A meta-analysis and systematic review of the literature. Inflamm Bowel Dis 2010;16:1077-84.

42. Koloski N-A, Bret L, Radford-Smith G. Hygiene hypothesis in inflammatory bowel disease: A critical review of the literature. World J Gastroenterol 2008;14:165-73.

43. Korzenik JR. Past and current theories of etiology of IBD: Toothpaste, worms, and refrigerators. J Clin Gastroenterol 2005;39:S59-65.

44. Hunter MM, Mckay DM. Helminths as therapeutic agents for inflammatory bowel disease. Aliment Pharmacol Ther 2004;19:167-77.

45. Summers RW, Elliott DE, Urban JF, Thompson R, Weinstock JV. Trichuris suis therapy in Crohn's disease. Gut 2005;54:87-90.

46. Summers RW, Elliott DE, Urban JF, Thompson RA, Weinstock JV. Trichuris suis therapy for active ulcerative colitis: A randomized controlled trial. Gastroenterology 2005;128:825-32.

47. Mendoza JL, Lana R, Diaz-Rubio M. Mycobacterium avium subspecies paratuberculosis and its relationship with Crohn's disease. World J Gastroenterol 2009;15:417-22.

48. Feller M, Huwiler K, Stephan R, et al. Mycobacterium avium subspecies paratuberculosis and Crohn's disease: A systematic review and meta-analysis. Lancet Infect Dis 2007;7:607-13.

49. Selby W, Pavli P, Crotty B, et al. Two-year combination antibiotic therapy with clarithromycin, rifabutin, and clofazimine for Crohn's disease. Gastroenterology 2007;132:2313-9.

50. García Rodríguez LA, Ruigómez A, Panés J. Acute gastroenteritis is followed by an increased risk of inflammatory bowel disease. Gastroenterology 2006;130:1588-94.

51. Gradel KO, Nielsen HL, Schønheyder HC, Ejlertsen T, Kristensen B, Nielsen $\mathrm{H}$. Increased short- and long-term risk of inflammatory bowel disease after salmonella or campylobacter gastroenteritis. Gastroenterology 2009;137:495-501.

52. Peeters H, Bogaert S, Laukens D, et al. CARD15 variants determine a disturbed early response of monocytes to adherent-invasive Escherichia coli strain LF82 in Crohn's disease. Int J Immunogenet 2007;34:181-91.

53. Strauss J, Kaplan GG, Beck PL, et al. Invasive potential of gut mucosa-derived Fusobacterium nucleatum positively correlates with IBD status of the host. Inflamm Bowel Dis 2011;17:1971-8.

54. Marteau P. Bacterial flora in inflammatory bowel disease. Dig Dis (Basel, Switzerland) 2009;(27 Suppl 1):99-103.

55. Joossens M, Huys G, Cnockaert M, et al. Dysbiosis of the faecal microbiota in patients with Crohn's disease and their unaffected relatives. Gut 2011;60:631-7.

56. Klement E, Lysy J, Hoshen M, Avitan M, Goldin E, Israeli E. Childhood hygiene is associated with the risk for inflammatory bowel disease: A population-based study. Am J Gastroenterol 2008;103:1775-82.

57. Radon K, Windstetter D, Poluda AL, Mueller B, von Mutius E, Koletzko S. Contact with farm animals in early life and juvenile inflammatory bowel disease: A case-control study. Pediatrics 2007;120:354-61. 
58. Wurzelmann JI, Lyles CM, Sandler RS. Childhood infections and the risk of inflammatory bowel disease. Dig Dis Sci 1994;39:555-60.

59. Bernstein CN, Blanchard JF, Rawsthorne P, Wajda A. Epidemiology of Crohn's disease and ulcerative colitis in a central Canadian province: A population-based study. Am J Epidemiol 1999;149:916-24.

60. Malekzadeh F, Alberti C, Nouraei M, et al. Crohn's disease and early exposure to domestic refrigeration. PloS One 2009;4:e4288.

61. Ananthakrishnan AN, Higuchi LM, Huang ES, et al. Aspirin, nonsteroidal anti-inflammatory drug use, and risk for Crohn disease and ulcerative colitis: A cohort study. Ann Intern Med 2012;156:350-9.

62. Felder JB, Korelitz BI, Rajapakse R, Schwarz S, Horatagis AP, Gleim G. Effects of nonsteroidal antiinflammatory drugs on inflammatory bowel disease: A case-control study. Am J Gastroenterol 2000;95:1949-54.

63. Takeuchi K, Smale S, Premchand P, et al. Prevalence and mechanism of nonsteroidal anti-inflammatory drug-induced clinical relapse in patients with inflammatory bowel disease. Clin Gastroenterol Hepatol 2006;4:196-202.

64. Bernstein CN, Singh S, Graff LA, Walker JR, Miller N, Cheang M. A prospective population-based study of triggers of symptomatic flares in IBD. Am J Gastroenterol 2010;105:1994-2002.

65. Berg DJ, Zhang J, Weinstock JV, et al. Rapid development of colitis in NSAID-treated IL-10-deficient mice. Gastroenterology 2002;123:1527-42.

66. Cornish JA, Tan E, Simillis C, Clark SK, Teare J, Tekkis PP. The risk of oral contraceptives in the etiology of inflammatory bowel disease: A meta-analysis. Am J Gastroenterol 2008;103:2394-400.

67. Timmer A, Sutherland LR, Martin F. Oral contraceptive use and smoking are risk factors for relapse in Crohn's disease. The Canadian Mesalamine for Remission of Crohn's Disease Study Group. Gastroenterology 1998;114:1143-50.

68. Cutolo M, Capellino S, Sulli A, et al. Estrogens and autoimmune diseases. Ann New York Acad Sci 2006;1089:538-47.

69. Reddy D, Siegel CA, Sands BE, Kane S. Possible association between isotretinoin and inflammatory bowel disease. Am J Gastroenterol 2006;101:1569-73.

70. Crockett SD, Porter CQ, Martin CF, Sandler RS, Kappelman MD. Isotretinoin use and the risk of inflammatory bowel disease: A case-control study. Am J Gastroenterol 2010;105:1986-93.

71. Bernstein CN, Nugent Z, Longobardi T, Blanchard JF. Isotretinoin is not associated with inflammatory bowel disease: A population-based case-control study. Am J Gastroenterol 2009; 104:2774-8

72. Shale M, Kaplan GG, Panaccione R, Ghosh S. Isotretinoin and intestinal inflammation: What gastroenterologists need to know. Gut 2009;58:737-41.

73. Gronlund MM, Lehtonen OP, Eerola E, Kero P. Fecal microflora in healthy infants born by different methods of delivery: Permanent changes in intestinal flora after cesarean delivery. J Pediatr Gastroenterol Nutr 1999;28:19-25.

74. Card T, Logan RFA, Rodrigues LC, Wheeler JG. Antibiotic use and the development of Crohn's disease. Gut 2004;53:246-50.

75. Hildebrand H, Malmborg P, Askling J, Ekbom A, Montgomery SM. Early-life exposures associated with antibiotic use and risk of subsequent Crohn's disease. Scand J Gastroenterol 2008;43:961-6.

76. Hviid A, Svanström H, Frisch M. Antibiotic use and inflammatory bowel diseases in childhood. Gut 2011;60:49-54.

77. Shaw SY, Blanchard JF, Bernstein CN. Association between the use of antibiotics in the first year of life and pediatric inflammatory bowel disease. Am J Gastroenterol 2010;105:2687-92.

78. Kaplan GG, Jackson T, Sands BE, Frisch M, Andersson RE, Korzenik J. The risk of developing Crohn's disease after an appendectomy: A meta-analysis. Am J Gastroenterol 2008;103:2925-31.

79. Kaplan GG, Pedersen BV, Andersson RE, Sands BE, Korzenik J, Frisch M. The risk of developing Crohn's disease after an appendectomy: A population-based cohort study in Sweden and Denmark. Gut 2007;56:1387-92

80. Kurina LM, Goldacre MJ, Yeates D, Seagroatt V. Appendicectomy, tonsillectomy, and inflammatory bowel disease: A case-control record linkage study. J Epidemiol Comm Health 2002;56:551-4

81. Koutroubakis IE, Vlachonikolis IG. Appendectomy and the development of ulcerative colitis: Results of a metaanalysis of published case-control studies. Am J Gastroenterol 2000;95:171-6.
82. Koutroubakis IE, Vlachonikolis IG, Kouroumalis EA. Role of appendicitis and appendectomy in the pathogenesis of ulcerative colitis: A critical review. Inflamm Bowel Dis 2002;8:277-86.

83. Frisch M, Gridley G. Appendectomy in adulthood and the risk of inflammatory bowel diseases. Scand J Gastroenterol 2002;37:1175-7.

84. Andersson RE, Olaison G, Tysk C, Ekbom A. Appendectomy and protection against ulcerative colitis. N Engl J Med 2001;344:808-14.

85. Mayer L, Eisenhardt D. Lack of induction of suppressor T cells by intestinal epithelial cells from patients with inflammatory bowel disease. J Clin Invest 1990;86:1255-60.

86. Wild GE, Drozdowski L, Tartaglia C, Clandinin MT, Thomson ABR. Nutritional modulation of the inflammatory response in inflammatory bowel disease - from the molecular to the integrative to the clinical. World J Gastroenterol 2007;13:1-7.

87. Reif S, Klein I, Lubin F, Farbstein M, Hallak A, Gilat T. Pre-illness dietary factors in inflammatory bowel disease. Gut 1997;40:754-60.

88. Russel MG, Engels LG, Muris JW, et al. Modern life in the epidemiology of inflammatory bowel disease: A case-control study with special emphasis on nutritional factors. Eur J Gastroenterol Hepatol 1998;10:243-9.

89. Amre DK, D'Souza S, Morgan K, et al. Imbalances in dietary consumption of fatty acids, vegetables, and fruits are associated with risk for Crohn's disease in children. Am J Gastroenterol 2007;102:2016-25

90. Sakamoto N, Kono S, Wakai K, et al. Dietary risk factors for inflammatory bowel disease: A multicenter case-control study in Japan. Inflamm Bowel Dis 2005;11:154-63.

91. Geerling BJ, Dagnelie PC, Badart-Smook A, Russel MG, Stockbrügger RW, Brummer RJ. Diet as a risk factor for the development of ulcerative colitis. Am J Gastroenterol 2000;95:1008-13.

92. Tjonneland A, Overvad K, Bergmann MM, et al. Linoleic acid, a dietary $n-6$ polyunsaturated fatty acid, and the aetiology of ulcerative colitis: A nested case-control study within a European prospective cohort study. Gut 2009;58:1606-11.

93. Jantchou P, Morois S, Clavel-Chapelon F, Boutron-Ruault M-C, Carbonnel F. Animal protein intake and risk of inflammatory bowel disease: The E3N prospective study. Am J Gastroenterol 2010;105:2195-201.

94. Ananthakrishnan AN, Khalili H, De Silva PS, et al. Higher dietary fiber intake is associated with lower risk of Crohn's disease but not ulcerative colitis - a prospective study. Gastroenterology 2010;142(Suppl 1):S-148.

95. Klement E, Cohen RV, Boxman J, Joseph A, Reif S. Breastfeeding and risk of inflammatory bowel disease: A systematic review with meta-analysis. Am J Clin Nutr 2004;80:1342-52.

96. Brock JH. The physiology of lactoferrin. Biochem Cell Biol 2002;80:1-6.

97. Koletzko S, Sherman P, Corey M, Griffiths A, Smith C. Role of infant feeding practices in development of Crohn's disease in childhood. BMJ (Clinical research edn) 1989;298:1617-8.

98. Thompson NP, Montgomery SM, Wadsworth ME, Pounder RE, Wakefield AJ. Early determinants of inflammatory bowel disease: Use of two national longitudinal birth cohorts. Eur J Gastroenterol Hepatol 2000;12:25-30.

99. Gilat T, Hacohen D, Lilos P, Langman MJ. Childhood factors in ulcerative colitis and Crohn's disease. An international cooperative study. Scand J Gstroenterol 1987;22:1009-24.

100. Ekbom A, Adami HO, Helmick CG, Jonzon A, Zack MM. Perinatal risk factors for inflammatory bowel disease: A case-control study. Am J Epidemiol 1990;132:1111-9.

101. Barclay AR, Russell RK, Wilson ML, Gilmour WH, Satsangi J, Wilson DC. Systematic review: the role of breastfeeding in the development of pediatric inflammatory bowel disease. J Pediatr 2009;155:421-6.

102. Armitage EL, Aldhous MC, Anderson N, et al. Incidence of juvenileonset Crohn's disease in Scotland: Association with northern latitude and affluence. Gastroenterology 2004;127:1051-7.

103. Nerich V, Monnet E, Etienne A, et al. Geographical variations of inflammatory bowel disease in France: A study based on national health insurance data. Inflamm Bowel Dis 2006;12:218-26.

104. Nerich V, Monnet E, Weill A, et al. Fine-scale geographic variations of inflammatory bowel disease in France: Correlation with socioeconomic and house equipment variables. Inflamm Bowel Dis 2010;16:813-21. 
105. Khalili H, Huang ES, Ananthakrishnan AN, et al. Geographical variation and incidence of inflammatory bowel disease among US women. Gut Jan 112012 (Epub ahead of print).

106. Peyrin-Biroulet L, Oussalah A, Bigard M-A. Crohn's disease: The hot hypothesis. Medical Hypoth 2009;73:94-6.

107. Ananthakrishnan AN, Khalili H, Higuchi LM, et al. Higher predicted vitamin D status is associated with reduced risk of Crohn's disease. Gastroenterology 2012;142:482-9.

108. Adams JS, Hewison M. Update in vitamin D. J Clin Endocrinol Metabol 2010;95:471-8.

109. Kaplan GG, Hubbard J, Korzenik J, et al. The inflammatory bowel diseases and ambient air pollution: A novel association. Am J Gastroenterol 2010;105:2412-9.

110. Ananthakrishnan AN, McGinley EL, Binion DG, Saeian K. Ambient air pollution correlates with hospitalizations for inflammatory bowel disease: An ecologic analysis. Inflamm Bowel Dis 2011;17:1138-45.

111. Kaplan GG, Dixon E, Panaccione R, et al. Effect of ambient air pollution on the incidence of appendicitis. CMAJ 2009;181:591-7.
112. Kaplan GG, Szyszkowicz M, Fichna J, et al. Non-specific abdominal pain and air pollution: a novel association. PLoS One 2012;7:e47669. Epub 2012 Oct 31.

113. Danese S, Sans M, Fiocchi C. Inflammatory bowel disease: The role of environmental factors. Autoimmun Rev 2004;3:394-400.

114. Mawdsley JE, Rampton DS. Psychological stress in IBD: New insights into pathogenic and therapeutic implications. Gut 2005;54:1481-91.

115. Lerebours E, Gower-Rousseau C, Merle V, et al. Stressful life events as a risk factor for inflammatory bowel disease onset: A populationbased case-control study. Am J Gastroenterol 2007;102:122-31.

116. Bitton A, Dobkin PL, Edwardes MD, et al. Predicting relapse in Crohn's disease: A biopsychosocial model. Gut 2008;57:1386-92.

117. Söderholm JD, Yang PC, Ceponis P, et al. Chronic stress induces mast cell-dependent bacterial adherence and initiates mucosal inflammation in rat intestine. Gastroenterology 2002;123:1099-108.

118. Mazzon E, Sturniolo GC, Puzzolo D, Frisina N, Fries W. Effect of stress on the paracellular barrier in the rat ileum. Gut 2002;51:507-13. 


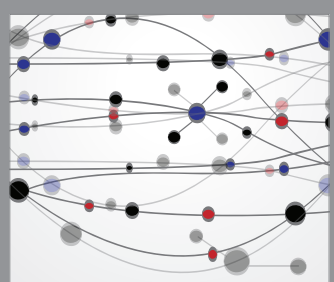

The Scientific World Journal
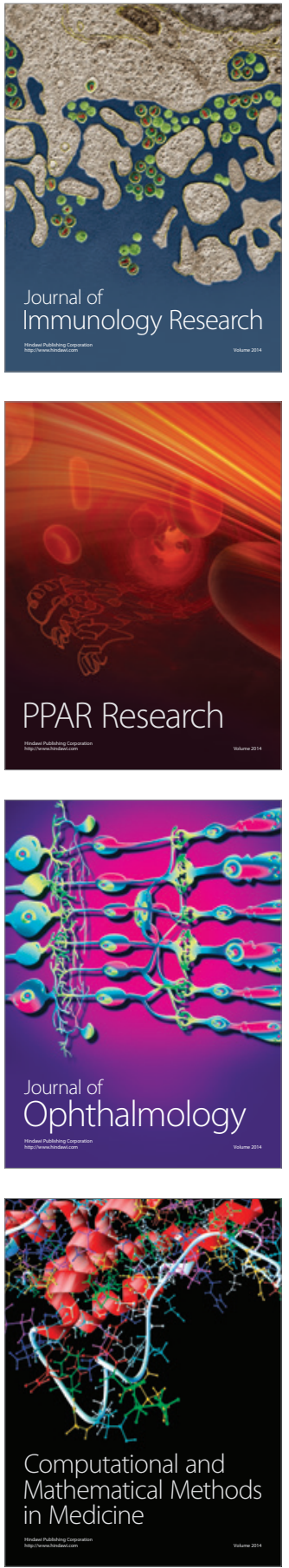

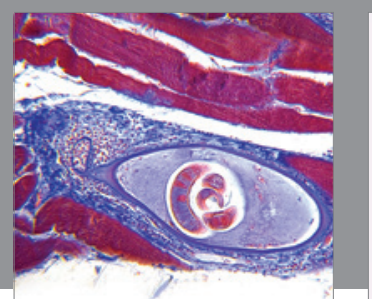

Gastroenterology Research and Practice

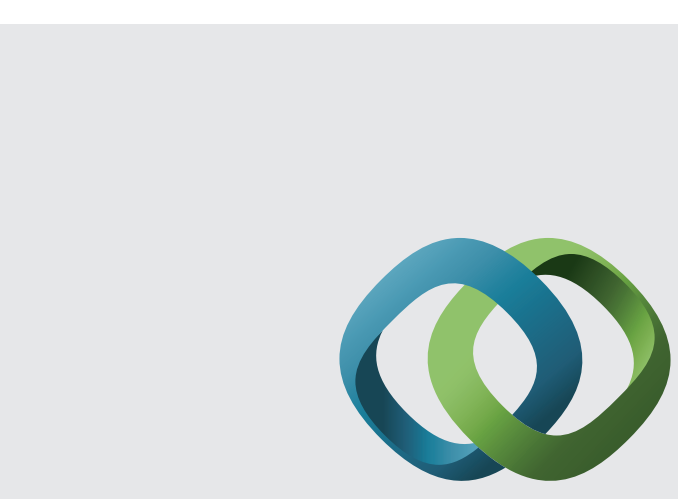

\section{Hindawi}

Submit your manuscripts at

http://www.hindawi.com
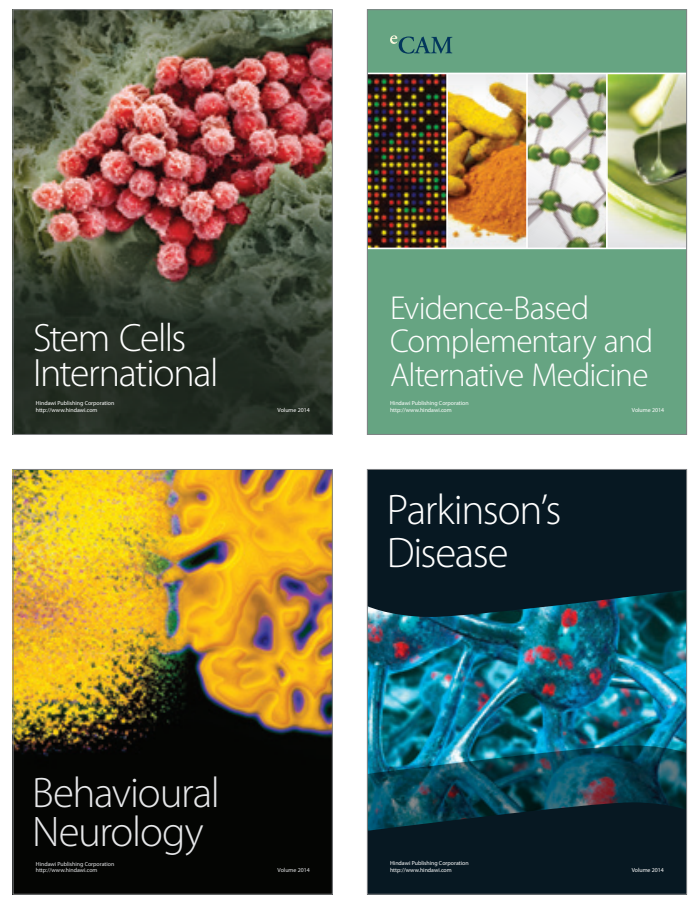
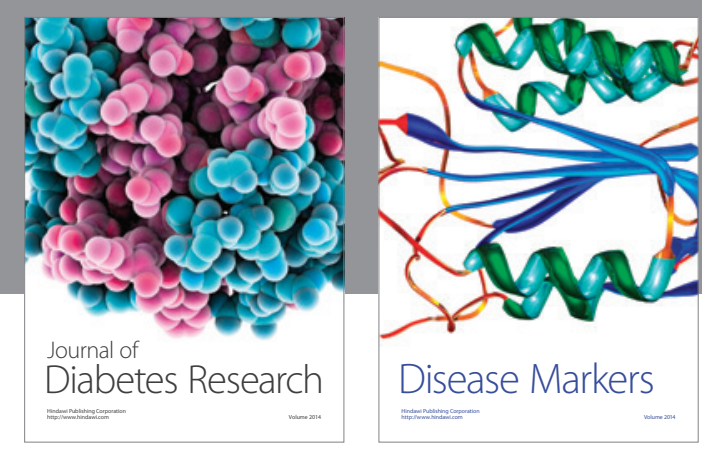

Disease Markers
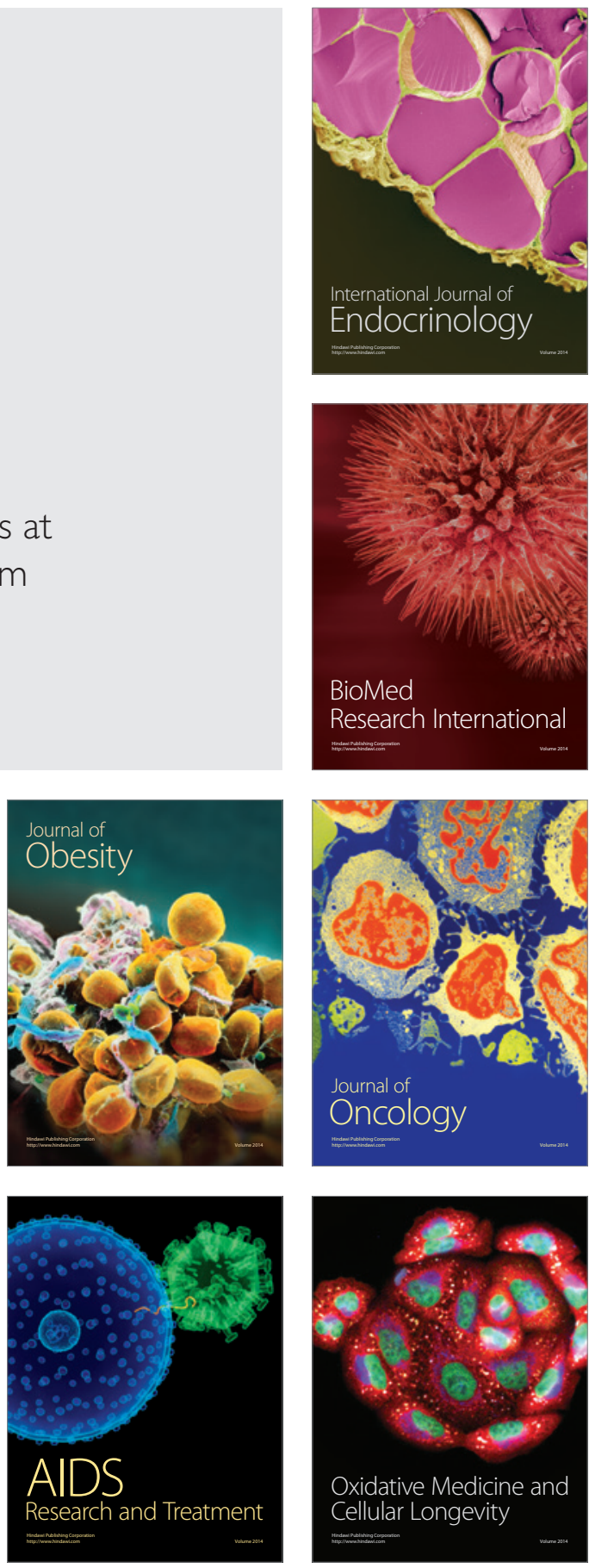